\title{
Possibilities of Soil Revitalization in Slovakia towards Sustainability
}

\author{
Emília Huttmanová ${ }^{1}$, Peter Adamišin ${ }^{1}$, Ondrej Hronec ${ }^{1}$, Jana Chovancová ${ }^{1}$
}

\begin{abstract}
Abtract
The quality of the environment in the Slovak Republic is considerably differentiated. Based on the comprehensive assessment of individual components of the environment, the territories with reduced quality of the environment (or some components of environment) were located in the process of environmental regionalization in the Slovak Republic. Damage and reduction of the environmental quality is mainly caused by anthropogenic activity and negatively influence the health and quality of life of the population living in these areas. To ensure sustainable development, it is necessary to eliminate negative impacts resulting from the reduced quality of the environment. The aim of this paper is to evaluate and propose options for soil revitalization in Slovakia, towards ensuring sustainability (especially in damaged areas). Soil recovery is now possible to perform using a variety of innovative and biological processes which are discussed in this paper. The realization of such soil revitalization could at least partially improve the current state of environmental quality (i.e. environmental sustainability) and, secondarily, in the quality of life and health of the population (social sustainability).
\end{abstract}

Keywords: Soil, revitalization, sustainability, environment

\section{Introduction}

Regions of the Slovak Republic have a different state of damage of the components of the environment, mainly due to anthropogenic activities. In the process of environmental regionalization, damaged regions were allocated. These regions with their specificities require a specific approach to the design and implementation of economic, social and environmental policies and activities so the activities carried out in these areas led towards sustainable development.

\section{Quality of environment in the Slovak republic}

In 1997 was established the Slovak Environmental Agency work group dedicated to specially vulnerable areas. On the basis of the state of the environment, environmental regionalization of the Slovak Republic has been developed. According SAŽP, environmental regionalization process is spatial division of the land in which, according to the established criteria and environmental characteristics of the selected files the regions with a certain quality of the environment and trends of environmental change were framed. These regions are characterized by the quality of the components of the environment, state of environmental risk factors and measures to protect the environment. In the process of environmental regionalization, 5 level of environmental quality was allocated, as indicated in Table 1. 
Table 1 Levels of environmental quality in Slovak Republic (SR)

\begin{tabular}{|l|c|c|}
\hline Environmental quality & Area in $\mathrm{km}^{2}$ & $\%$ of total territory of SR \\
\hline Level 1 - high quality environment & 23007 & 46,9 \\
\hline Level 2 - satisfactory environment & 11034 & 22,5 \\
\hline Level 3 - moderately deteriorated environment & 8380 & 17,1 \\
\hline Level 4 - deteriorated environment & 5235 & 10,7 \\
\hline Level 5 - heavily deteriorated environment & 1378 & 2,8 \\
\hline
\end{tabular}

Source: SAŽP; Note: Data for 2010 (update for 2014 is not yet processed and available)

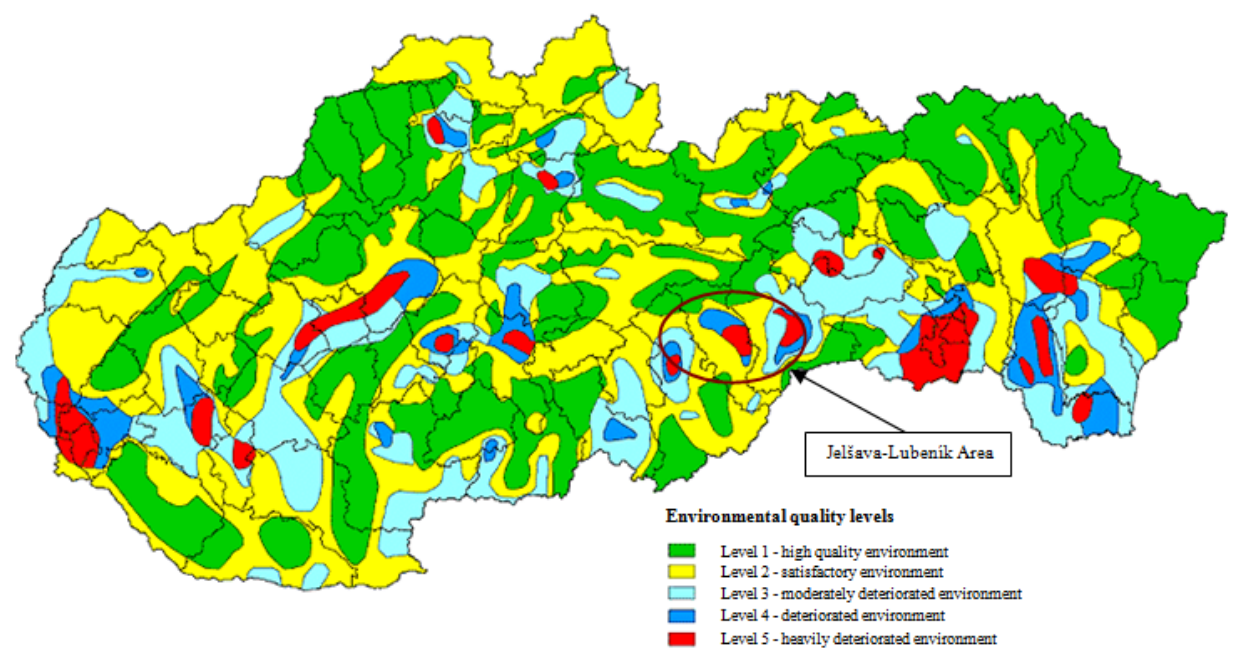

Figure 1 Map of environmental quality levels in Slovakia

Source: $S A Z P$

Areas classified as an area with a high level of environment quality (1st level) represent the regions least negatively affected by human activities. On the contrary, the territories included in the level 5 of environmental quality represent areas extremely adversely affected by human activities - the areas with the highest share of environmental burdens and ecological problems reflected in a change of environmental quality.

According to the newest approach in the process of environmental regionalization, based on five levels of environmental quality, geomorphological conditions and other geographical or administrative specificities, three basic types of environmental quality regions were defined (Klinda, Bohuš, Semrád, 2005):

- Regions of the first level of environmental quality - this type of region cover mainly the environment of high quality (level 1).

- Regions of the second level of environmental quality - this type presents a transitional area, which is highly heterogeneous. The dominant regions are these with satisfactory environment (level 2) with a moderately deteriorated environment (level 3).

- Regions of the third level of environmental quality - represent the area where environmental burdens are cumulated; the area is mostly heavily deteriorated environments (level 5) and deteriorated environment (level 4)

Based on a comprehensive assessment of the state of the atmosphere, the quality of groundwater and surface water, soil, rock environment, biota and other factors, the risk (problematic) areas have been identified. These areas are identified as Level 4 - deteriorated environment and Level 
5 - heavily deteriorated environment (Table 1). Recently they present almost $16 \%$ of the total land area and are inhabited by more than $37 \%$ of the total population (SAŽP and enviropotal, 2012).

In these regions, there are different problems of individual components of the environment such as excessive load of $\mathrm{SO}_{2}, \mathrm{NO}_{x}, \mathrm{CO}$ emissions, decreased quality of groundwater and surface water, but also significantly deteriorated soil and soil contamination. Problems in the environmental field are then reflected on the health of the population and reduced quality of life of people living in these areas. As indicated earlier, these areas are inhabited by more than two millions of inhabitants.

In some polluted areas the soil is contaminated by heavy metals (such as nickel in Galantská area, or Cadmium, lead and copper in the Upper Nitra region), in other areas soils are strongly acidified resp. alkalized. To ensure sustainable development (in all its dimensions - i.e. economic, environmental, but also social) in these regions is necessary to eliminate negative impacts resulting from the reduced quality of the environment. The revitalization of contaminated land is an essential part of the improvement of the environment and elimination the negative effects of previous anthropogenic activities.

\section{Soil alkalization as a special problem in selected areas}

The aim of this paper is to evaluate the possibilities of revitalization of the soil in Slovakia (in example of biological revitalization performed in the selected burdened area) which should be directed to ensure sustainable development (and its dimensions).

The quality of soil resource as one of the fundamental components of the environment as well as agro-ecological conditions in the Slovak Republic is diversified. As a result of previous orientation of the national economy to build heavy industry based on high energy and raw material intensity, occurred in our country the (excessive) contamination of soil, which has negatively affected the quality of the environment including the soil characteristics.

The consequences of industrial activity resulted mostly in soils acidification, alkalization and metallization. Alkalinisation of soils is largely the result of alkaline, mostly particulate imissions and despite the fact that in Slovakia it is not so widespread phenomena, from the milder impact on soil, e.g. surroundings of cement and lime plants, it can have highly devastating effects (e.g. in the areas of magnesite processing plants). Endogenous resources of soil alkalinisation are particularly heavily mineralized groundwater, causing soil salinization associated with alkalization. Salinization and alkalinisation of soils greatly reduces agricultural production. Alkalinisation of soils in Slovakia is caused mainly by anthropogenic activities.

Slovak republic is a country extremely rich in the natural crystal magnesite. The Slovak Republic is the fourth largest producer of magnesite in the world. On the territory of Slovakia is produced more than $6.5 \%$ of world production of magnesite. Mining and processing of magnesite is also a major economic sector of the Slovak national economy. The production of magnesite is localized on sites Jelšava (Slovak Magnesite Plant in Jelšava) and Lubeník (SLOVMAG Lubeník). Extraction of magnesite and subsequent processing is a very dusty process. Production of magnesite clinkers is conducted by thermal decomposition and clinker process. These companies have affected by its production not only air quality, but mainly the quality of soils, which are due to the extraction and processing of magnesite highly alkalized. A strong alkalinisation of soils caused heavy deterioration of soils in some sites placed in the immission field of above mentioned companies to the extent that the microbial life there has disappeared. In these areas are soil also significantly metalized (with the high doses of heavy metals, in particular $\mathrm{Hg}, \mathrm{Mn}, \mathrm{As}, \mathrm{Cd}, \mathrm{Pb}, \mathrm{Cu}$, $\mathrm{Al}, \mathrm{Fe})$. Heavy metals are a leading group of contaminants, which is involved in changing soil properties and significantly interferes with the processes occurring in the soil environment. (Javoreková a kol. 2008). 
Jelšava-Lubeník area (figure 1) where the mining and processing of magnesite is concentrated, has become one of the most polluted areas of the Slovak Republic, where is present strong alkalinisation of the soil. In this area, during the processing of magnesite, magnesium oxide is emitted into the atmosphere. Magnesium oxide causes the alkalinisation of more than 12000 hectares of agricultural land and more than 6,600 ha of forest land. In this area, the soil $\mathrm{pH}$ is around 8-9, which corresponds to a strong alkalinisation of soils. Magnesium imissions cause many undesirable phenomena on soil, vegetation and animals, reflected also in many adverse events such as poorer production and economic results. These events led to the collapse of indigenous plant communities on soils in imission field of above mentioned companies and only a few resistant species insignificant from production, agricultural, forest and aesthetics point of view are present there. Alkalinisation of soils and accumulation of other environmental problems in this area have arisen primarily to reduced crop production. In some areas, strong alkalinisation caused loss of production ability of soil where any plant is hard to be grown.Adjusting soil $\mathrm{pH}$ towards neutralizing the soil is quite difficult and long-term process. Adjusting soil $\mathrm{pH}$ is economically but also very time consuming. One of the options in the process of adjusting soil properties and revitalization of damaged soils is the use of biological processes.

\section{Possibilities of alkalized soil revitalization by phytomass as a way of sustainable revitalization}

Landscape revitalization is a complex and highly complicated process. Represents the active implementation of measures aimed at full operationalization of ecosystem functions services (nature, biodiversity, etc.), which country provides and which are focus on improving the quality of the existence and survival of organisms and ultimately also for sustainable human life There are most important revitalization measures in the country - agriculture, forestry and water management measures.In connection with the revitalization of the country is necessary mention of the potential and strength of the country, because in many places were caused by anthropogenic activities to their restriction or distortion, and this is what gives need of country (components of environment) revitalization in the present. Revitalization, in essence, means renewal of vital functions, (re) recovery, strengthening, recovery, renaturation, or restore soil fertility generally after damage by human activities.

Revitalization of damaged soils is one of the possibilities for the preservation of their production and non-production characteristics and ensuring sustainable development. Revitalization is an increase of its ecological stability of country and the possibility of providing its sustainability (Novotný 2012). About other possibilities of revitalization of soil contaminated by anthropogenic activity deals aslo Vráblíková, Vráblík (2002).

Long-term observation and our previous research showed, that in this contaminated area the Phragmites australis (Cav.) Trin appeared in last years. This plant represents one of methods of contaminated soil revitalization. Phragmites australis (Cav.) Trin is originally humid plant, but in this area it grows literally in dry sites, where ground water is in the depth of several metres. Striking vitality of Phragmites australis (Cav.) Trin was found, as mega population in more sites, where the $\mathrm{pH}$ value reached more than 9 (which is on the border of strongly alkalized soil) and in such sites, where it does not occur and according to the published statements its presentation was not recorded in the past. It is hopeful, dominant, resistant, anti-erosive and technically available kind providing alternative solution of sanitation and fertilization of contaminated soils.

Phragmites australis (Cav.) Trin can be considered very suitable plant for revatalization and remediation of contaminated soils through biological processes.

In the imission field of exhalation sources of Slovak magnesite plants Jelšava and Slovmag Lubeník we conducted a further study to survey the species, which should be characterized by 
increased resistance and could have potential properties such has Phragmites australis (Cav.) Trin. However, Phragmites australis (Cav.) Trin proved for purpose as the most suitable crop for several reasons. Therefore, we further verified the various methods of reproduction of Phragmites australis (Cav.) Trin., so that growing of this plant on contaminated soil was the most economically efficient. We have verified the vegetative and generative methods of reproduction, and we came to the conclusion that the generative reproduction appears to be more efficient (also in terms of next generation of biomass). It was subsequently verified the intensity (speed) of growth and biomass production in the process of growth and it has been established that the method of reproduction does not affect the formation of biomass (production of leaves).

\section{Other benefits of phytomass used in the process of alkalized soil revitalization towards sustainability}

Currently our research is focused on the possible use of Phragmites australis as an alternative energy source. This is in line with the current EU objectives of renewable energy use and sustainable development. The EU aims to achieve a higher proportion of energy from renewable sources (for 2020 should so called green energy represent 20 percent of total energy consumption). Increasing share of renewable energy is also one of the main priorities of the Energy Policy of Slovak republic (Ministry of Environment).

Although current trends in the use of phyto-biomass for energy purposes move towards the use of cereals, but also other alternative and economically efficient sources are sought. E.g. maize as energy crop has many disadvantages - high inputs, fluctuations in harvest, the risk of soil erosion and limited area for cultivation (Jamriška, P). From traditional crops are best cereals (triticale, rye), including straw, while the straw energy efficiency is higher than the combustion of entire plants. For other crops can be grown for energy purposes e.g. Brassica napus, Helianthus annuus but also, for example, the grasses - Festuca arundinacea, Arrhenatherum elatius, Phragmites communis etc. About othe possibilities of using of biomass deals Bejda et al. (2002); Horbaj (2006),

Table 2 Energy recovery of selected phytomass

\begin{tabular}{|l|c|c|c|}
\hline & $\begin{array}{c}\text { Combustion heat in } \\
\text { MJ.kg-1 } \text { of dry weight }^{-17,7}\end{array}$ & $\begin{array}{c}\text { Harvest of dry } \\
\text { substance in t.ha }\end{array}$ & $\begin{array}{c}\text { Energy recovery in } \\
\text { GJ.ha }^{-1}\end{array}$ \\
\hline Phragmites australis & 17,6 & 223 \\
\hline Sorghum bicolor L. Moench & 17,6 & 9,83 & 173 \\
\hline Sorghum bicolor var. saccharatum & 17,8 & 10,2 & 182 \\
\hline camelina sativa & 18,8 & 2,11 & 39,7 \\
\hline Cannabis sativa & 18,1 & 12,05 & 218 \\
\hline Artemisia vulgaris & 17,6 & 15,4 & 271 \\
\hline
\end{tabular}

Source: Porvaz, Naš́áková, Kotorová, Kováč, 2009

Targeted production of phytobiomass for energy use has a unique importance both for the acquisition of renewable energy, but also for the use of marginal and disadvantaged areas in the regions of Slovakia (Porvaz, Naščáková, Kotorová, Kováč, 2009).

In the process of using Phragmites australis as energy crops, however, still problematic seems to be possible transfer of contaminants (from alkalized soil) through biomass into the air. Solutions to this problem and verifying energy efficiency of Phragmites australis is the aim of our further research

In verifying the possibility of using Phragmites australis (Cav.) Trin. for energy purposes, we concluded that it is possible to suggest this crop to produce pellets for combustion, or even the production of briquettes. Phragmites australis after such processing has good heat value, which is 
comparable with a heat value of lignite. It presents a significant array of possibilities for its use as biofuel. Furthermore, besides energy efficiency also economic feasibility of growing the crop is also obvious. Phragmites australis (Cav.) Trin. might be a determining crop in the process of biological revitalization of soils, but also in the process of renewable energy use, with relatively low economic demands related to its growing and high economic efficiency of the process of its use as a renewable energy source. The benefits of growing Phradgmites australis are also evident in the field of sustainable development, but in particular in the environmental and economic dimension.

\section{Conslusion}

Increasing of fertility of contaminated soil requires significant financial funding. Growing Phragmites australis at the contaminated sites provides a cheaper and more effective alternative to the chemical or technical revitalization of the soil. The biomass of the Phragmites australis also provides additional "green" ways of use (e.g. production of green energy), which seems to be desirable in the process of enhancing sustainable development. Soil revitalization using biological processes, such as growing Phragmites australis at least partially leads towards improving the quality of the environment (i.e. the improvement in the environmental site of sustainable development) and secondarily in terms of quality of life and health of the population (i.e. the improvement of the social site of sustainable development).

\section{Acknowledgement}

"Paper is the result of the Project implementation: University Science Park TECHNICOM for Innovation Applications Supported by Knowledge Technology, ITMS: 26220220182, supported by the Research \& Development Operational Programme funded by the ERDF."

\section{References}

Angelovičová, L., Fazekašová, D. 2014. Contamination of the soil and water environment by heavy metals in the former mining area of Rudňany (Slovakia). Soil \& Water Res.,9, 2014 (1): 18-24.

Bejda, J., Kádárová, J., Krepelka, F., Miklúšová, V.: Laboratórny výskum briketovatel’nosti bioodpadu. In. Technika ochrany životného prostredia (TOP) 2002, 22.-23. máj, STU Bratislava, Častá Papiernička, s. 229-234

Cluis, C.: Junk-greedy Greens: phytoremediaton as a new option for soil decontamination. In. Biotechnology journal. ISSN 1860-7314, 2004, vol. 2, p. 61-67.

Fazekašová, D., Huttmanová, E., Fazekaš, J. 2014. Time and Spatial Variability of Physical and Chemical soil Parameters in Conditions of the Sustainable Soil Use in Carpatian region Management 2014. International conference Management 2014. s. 421-424. ISBN 978-80-8165-052-9.

Demirbaş, A., Şahin, A.: Evaluation of biomass residues - briquetting waste paper and wheat-straw mixtures. Fuel processing technology, 55 (2). 1998 pp. 175-183

Demirbaş, A.: Evaluation of biomass material as energy sources - upgrading of tea waste by briquetting process, Energy sources 21 (3). 1999 pp. 215-220

Enviroportal. Správy o stave životného prostredia v Slovenskej republike. http://enviroportal.sk

Horbaj, P.: Možnosti využívania biomasy v SR. In.: Acta Montanistica Slovaca, roč. 11, 2006, s. 258-263

Hronec, O., Huttmanová, E., Chovancová, J. 2009. Ekonomika životného prostedia. Prešov : PU v Prešove, s. 142. ISBN 978-80-555-0056-0

Hronec, O., Hajduk, J.: Significant resistence of Phragmites australis Cay. Trin. On the soils intoxicated with magnesium immissions. Ecology, no. 2, 1996, pp. 117-124

Jamriška, P. 2007. Rastlinná výroba - zdroj obnovitel’nej energie. In Predpoklady využívania pol’nohospodárskej a lesníckej biomasy na energetické a biotechnické využitie. Nitra : SAPV s.2027. ISBN 978-80-89162-32-1. 
Javoreková, S. at al:: Biológia pôdy v agroekosystémoch. Vydavatel’stvo: Slovenská pol’nohospodárska univerzita v Nitre, 2008, pp. 349 ISBN: 978-80-5520-007-1

Klinda, P., Bohuš, B., Semrád, P. 2005. Environmentálna regionalizácia Slovenskej republiky. In: Enviromagazín, 3/2005. s. 14 - 15. ISSN 1335-1877.

Ministry of Environment of the Slovak Republic; http://minzp.sk

Novotný,J. 2012. Revitalizácia krajiny a jej trvalo udržatel'né obhospodarovanie-strategický ciel' Slovenska. In Novotný, J., Konôpka, J., Midriak, R.,Šimková, D. (ed.) 2012. Revitalizácia krajiny a integrovaný manažment povodí ako vedecký problém. Zborník SAPV č. 71.Nitra: Agentúra SAPV, s. 11-16

Porvaz P., Naščáková, J., Kotorová, D., Kováč, L. 2009. Pol’né plodiny ako zdroj biomasy na energetické využitie v podmienkach Slovenska. In: Inovatívne technologie pre efektívne využitie biomasy v energetike. s. 66 - 75. ISBN 978-80-225-2962-4. Dostupné na: http://enersupply.euke.sk/wpcontent/uploads/66-75_porvaz-nascakova-kotorova-kovac.pdf

Slovak Agency od Environment; http://sazp.sk

Stratégia vyššieho využitia obnovitel'ných zdrojov energie v SR; MH SR, Bratislava, 2006.

Vráblíková J., Vráblík P.: Zkušenosti s revitalizací antropogenně postižené půdy. str. 40-42 ISBN 80-8887025-9. Zborník z 3. mezinárodní konference „Zivot v pôdě“ 29.1.2002 Ústav krajinnej ekologie SAV Bratislava, 2002. 
